\title{
Some factors limiting the success of Lotus corniculatus in hill and high country
}

\author{
H.M. Chapman', W.L. Lowther ${ }^{2}$ and K.D. Trainor ${ }^{2}$ \\ ${ }^{1}$ Tara Hills, MAFTech, Omarama \\ ${ }^{2}$ Invermay Agricultural Centre, MAFTech, Mosgiel
}

ABSTRACT Establishment and management problems have been identified as limitations to the productivity of birdsfoot trefoil (Lotus corniculatus L.) in hill and high country environments. Nodulation failures owing to ineffective inoculation techniques, low seedling vigour, and slow initiation of symbiotic nitrogen fixation are major problems in establishment. Competition from resident species and inappropriate grazing management can lead to poor persistence and stand performance. Recommendations to improve establishment, persistence and productivity include inoculating at 5 times the manufacturer's stipulated rate and drilling, within 24 hours of inoculation, at no more than $12 \mathrm{~mm}$ depth Weed control is essential. Stands should be sown pure or with non aggressive companion species, and rotationally grazed.

Keywords Lotus corniculutus, birdsfoot trefoil, establishment, $\mathrm{N}$ fixation, inoculation, management

\section{INTRODUCTION}

Birdsfoot trefoil (Lotus corniculatus L.) has potential as a productive and persistent legume for moderately fertile, drier hill and high country (Scott \& Charlton 1983). Because it is more tolerant of soil acidity than lucerne (Medicago sativa L.), it may have potential for use on dry soils where soil acidity limits the persistence of luceme, such as the outwash yellowbrown earth soils of the Mackenzie Basin (Widdup et al. 1987). However, runholders have reported difficulties in obtaining satisfactory productivity from stands of birdsfoot trefoil which may be due to problems with establishment or persistence, or both.

In this paper we review and investigate some possible causes for these problems, and put forward recommendations to improve the reliability of establishment and to increase persistence.

\section{SURVEY OF BIRDSFOOT TREFOIL PERFORMANCE}

Fifteen stands of birdsfoot trefoil in Central Otago, Upper Waitaki and the Mackenzie Basin were surveyed to study possible relationships between environmental factors and stand density (Table 1).

Stands varied in cover density from a few scattered individuals to good uniform cover. The numbers of stands with a poor cover density index supports the claims of runholders over the difficulty with establishment and persistence. Although there was no information on initial establishment, the apparent lack of correlation between environmental factors and stand cover index strongly suggests that initial establishment failure was a major reason for the poor birdsfoot trefoil cover identified in the survey.

Table 1 Location, rainfall' and edaphic ${ }^{2}$ factors in relation to cover $^{3}$ of birdsfoot trefoil.

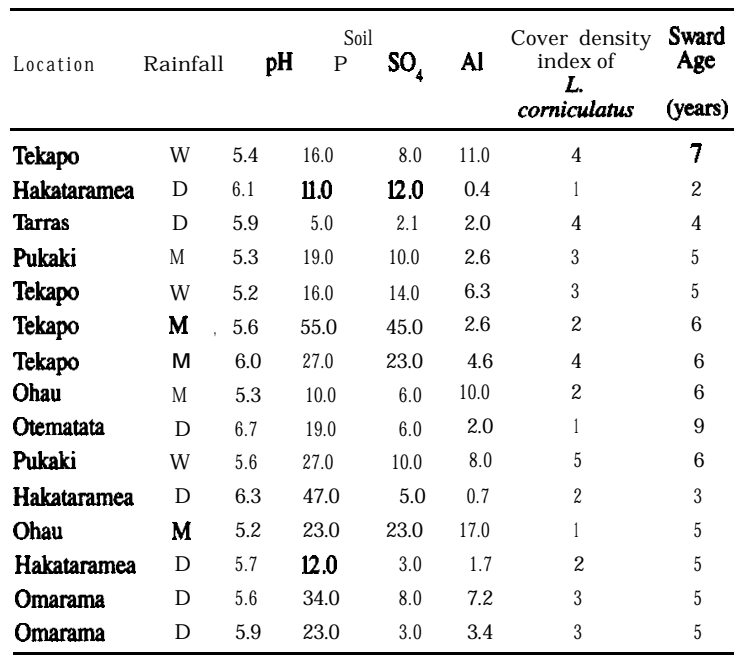

1 Wet, Moist, Dry (Hughes 1973)

${ }_{3}^{2}$ MAF Quick Tests

Cover density index 1-5 $(1=$ few scattered plants, 5 good uniform cover)

\section{INOCULATION AND PELLETING}

Rhizobia infective on birdsfoot trefoil are absent from New Zealand soils except for those few areas where L. tenuis L. or birdsfoot trefoil have become naturalised (Greenwood \& Pankhurst 1977), and hence inoculation with effective rhizobia is essential for nodulation. Scott \& Charlton (1983) suggested commercially inoculated and coated seed or else inoculation immediately before use. Lowther \& Trainor (1988) specifically recommended inoculation at 5 times the manufacturer's stipulated rate, the incorporation of $10 \%$ gum arabic in the slurry, and oversowing within 24 hours. Although developed for 
oversown birdsfoot trefoil, this recommendation is relevant to overdrilled seed (Table 2; Lowther unpub. results).

The inoculation problem is related to rapid death of rhizobia on the seed. In the overdrilled experiment (Table 2), inoculation at the manufacturer's stipulated rate supplied $2.1 \times 10^{4}$ rhizobia per seed at inoculation, but the numbers declined rapidly in the first 24 hours to 360 and 1030 per seed in slurry inoculation and gum arabic treatments, respectively. Most of the decline occurred in the first 3 hours after inoculation, suggesting a sensitivity to desiccation or seed toxins.

Table 2 Effect of inoculation, pelleting and days between inoculation and overdrilling (1 or 4 days' storage) into a yellowgrey earth $(\mathrm{pH}$ 5.6) on the percentage of birdsfoot trefoil plants with nodules and foliage weight.

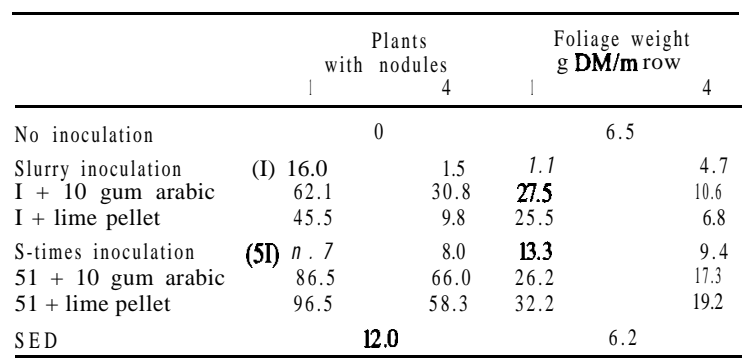

'Rhizobia per seed at inoculation $=2.1 \times 10^{4}$

Although birdsfoot trefoil is less sensitive to acidity than lucerne, Lowther \& al. (1987) concluded that soil acidity could be expected to limit the use of birdsfoot trefoil on more acid soils $(\mathrm{pH}<5.0)$ in the absence of broadcast lime. Nodulation failure can limit establishment of birdsfoot trefoil on acid soils, although the effect can be modified by both broadcast lime and seed pelleting (Table 3; Lowther, unpub. results). There was a virtual nodulation failure on the two most acid sites in the absence of broadcast lime, and although broadcast lime increased nodulation, only $18 \%$ and $37 \%$ of seedlings were nodulated even with the best pelleting treatment. On the least acid site $(\mathrm{pH}$ 5.2) in the absence of broadcast lime, nodulation was highest in the $\mathrm{x} 5$ inoculated lime pelleted treatment. At the normal inoculation level, lime pelleting had no apparent effect on nodulation, indicating the need for adequate populations of rhizobia before pelleting can stimulate nodulation. We therefore recommend that birdsfoot trefoil seed sown on acid soils (around $\mathbf{p H}$ 5.5 and less) should be inoculated at 5 times the stipulated rate, lime coated and sown within one day. On more acid soils (around pH 5.0 and below) establishment failures are likely without the application of broadcast lime. No information is available on commercial pelleting of birdsfoot trefoil.

\section{SEEDLING GROWTH}

In the US, birdsfoot trefoil is considered difficult to establish because of poor seedling vigour (Matches 1989). Establishment failures attributable to sowing too deep have been observed in Otago after sodseeding and drilling into cultivated ground, particularly after uneven paddock consolidation. American work (Seaney \& Henson 1970) has led to a recommendation to seed no deeper than $13 \mathrm{~mm}$.

The importance of herbicide application to control existing vegetation before sod-seeding is well understood. However, sorrel (Rumex acetosella L.) has proved difficult to control in the semi-arid environment of Central Otago (Brash 1983) and further investigations into specific herbicide requirements for this environment, with emphasis on both reliability and cost, are under way (Mitchell pers. comm.). Although post-emergence herbicides can control competing vegetation (Seaney \& Henson 1970), cost will usually preclude their use on hill and high country, and hence strategic grazing may be necessary to control competition for light and nutrients.

The application of fertiliser nitrogen at sowing is not recommended for establishing clover-based pastures on hill and high country soil even under low fertility conditions (Cullen 1971). However, recent research strongly suggests that nitrogen stress can limit the survival of birdsfoot trefoil seedlings (Lowther et al. 1989) owing to a slow initial onset and rate of symbiotic nitrogen fixation. In soils low in available

Table 3 Effect of inoculation, pelleting and broadcast lime (0 or $1000 \mathrm{~kg} /$ ha) on percentage of birdsfoot trefoil seedlings nodulated on 3 sites of different soil $\mathbf{p H}$.

\begin{tabular}{|c|c|c|c|c|c|c|}
\hline & $\begin{array}{l}\text { Hindon } \\
0\end{array}$ & $\underset{1000}{(\mathrm{pH}} 4.6)$ & $\underset{0}{\text { Lammermoor }}$ & $\underset{1000}{(\mathrm{pH} 4.9)}$ & $\begin{array}{c}\text { Middlemarch } \\
0\end{array}$ & $\underset{1000}{(\mathrm{pH} 5.2)}$ \\
\hline $\begin{array}{l}\text { Slurry inoculation (I)' } \\
\mathrm{I}+1 \mathrm{~g} \text { umarabic } \\
\mathrm{I}+\text { lime pellet }\end{array}$ & $\begin{array}{l}0 \\
1 \\
0\end{array}$ & $\begin{array}{r}4 \\
13 \\
11\end{array}$ & $\begin{array}{l}0 \\
1 \\
3\end{array}$ & $\begin{array}{l}1 \\
8 \\
4\end{array}$ & $\begin{array}{r}10 \\
29 \\
19\end{array}$ & $\begin{array}{l}11 \\
32 \\
40\end{array}$ \\
\hline $\begin{array}{l}\text { 5-times inoculation (5I) } \\
51+19_{u \text { marabic }} \\
51+\text { lime pellet }\end{array}$ & $\begin{array}{l}0 \\
1 \\
4\end{array}$ & $\begin{array}{r}6 \\
16 \\
37\end{array}$ & $\begin{array}{l}0 \\
1 \\
5\end{array}$ & $\begin{array}{c}1 \\
9 \\
18\end{array}$ & $\begin{array}{l}11 \\
24 \\
49\end{array}$ & $\begin{array}{l}36 \\
60 \\
64\end{array}$ \\
\hline SED & \multicolumn{2}{|c|}{4.2} & \multicolumn{2}{|c|}{2.7} & \multicolumn{2}{|c|}{7.0} \\
\hline
\end{tabular}

'Rhizobia per seed at inoculation $=2.5 \times 10^{4}$. Seed sown day following inoculation. 
soil nitrogen early seedling growth is slow and the small seedlings with restricted root systems are exposed to drought stress and consequent death with the onset of dry summer conditions. On sites with higher levels of available soil nitrogen seedling growth is more rapid and the larger, deeper-rooted seedlings are more able to withstand the onset of drought. This problem will be most severe when birdsfoot trefoil is sod-seeded into undeveloped tussock grassland soil. Research is under way into developing technology to provide a small amount of nitrogen to the legume seedling to increase growth without affecting seed germination or stimulating the competing vegetation. Recent research with grass establishment in similar environments provides some guidelines (Pollock 1989).

\section{PESTS AND DISEASES}

Birdsfoot trefoil is less resistant than Maku lotus ( $L$. pedunculatus) to pasture pests such as grass grub (Costelytra zealandica) (Farrell \& Sweney 1974) and broad-nosed weevils (Curculionidae; Leptopiinae) (Barratt pers. comm.). Severe grass grub damage has been observed in coastal Otago where insecticide was not applied with the seed in a paddock with a high population of grass grub. Hence insect assessments and control where necessary can be essential for establishment.

Crown and root rots are considered the most important diseases of birdsfoot trefoil in the US (Seaney \& Henson 1970), particularly in the warmer southern areas. Scott \& Charlton (1983), in commenting on observational trials that indicated high persistence and continued production under moderate soil fertility of the drier hill and high country, make no mention of disease problems. Recently, however, crown and root rots have been identified as a potential problem in some areas of Otago. In one oversown trial near Middlemarch around 50\% of 3-year-old plants died in winter-early spring, leaving large areas of bare ground and sub-optimal plant density. In the same area, death of 1 \&month-old plants in a sown paddock has been observed over summer. Dead plants were infected with a complex of Fusarium species, causing a basal rot.

\section{NATURAL RESEEDING}

In areas of the US where the perennial habit of birdsfoot trefoil is shortened by management, environment or disease, natural reseeding is considered to contribute to its long term persistence in pastures (Seaney \& Henson 1970).

Spelling of first or second-year stands to allow seeding is being investigated in Otago to increase plant density where problems in establishment have occurred, and to build up seed banks in the soil for long term persistence of the sward (Ogden pers. comm.). Once a stand has set seed, mob grazing is recommended to trample the seeds into the soil. The importance of rhizobia spread in the noduation of new seedlings is also being investigated (Lowther pers. comm.).

\section{COMPANION SPECIES}

Birdsfoot trefoil may be sown alone or in association with a grass or herb. However, because of the low legume seedling vigour, establishment failures can occur if the companion grass exerts too much competition. Cross-drilling grasses and birdsfoot trefoil is therefore recommended.

Although the life of the stand may be shortened, the inclusion of a companion species will reduce weed competition and spread production over a longer period. Suitable species should be slow to establish, and not too aggressive. Species with early spring or autumn activity may have a place to complement the summer production of birdsfoot trefoil under grazing. Possible companion species include 'Grasslands Maru' phalaris (Phalaris aquatica L.), tall fescue (Festuca arundinacea Shreb.), 'Grasslands Matua' prairie grass (Bromus willdenowii Kunth.) and sheep's bumet (Sanguisorba minor L.), but further evaluation of such mixtures is required. Highly competitive grasses such as 'Grasslands Wana' cocksfoot (Dactylis glomerata L.) and ryegrass (Lolium perenne L.) are not recommended as they will eventually dominate the mixture.

\section{GRAZING MANAGEMENT}

Failure of birdsfoot trefoil stands in this survey could not be shown to be the result of mismanagement because of lack of establishment record, but it may have been a factor in determining stand persistence.

Recommended grazing management for established birdsfoot trefoil is similar to that of luceme (Scott \& Charlton 1983). Ideally it should be defoliated at a relatively mature stage of growth Set stocking, or hard defoliation with short intervals between grazing, will lead to a rapid decline of birdsfoot trefoil, but if plants show a lack of vigor because of mismanagement they can be improved by adequate spelling.

\section{SUMMARY}

Birdsfoot trefoil has potential as a legume for the drier hill and high country but because of problems, particularly with inoculation and seedling vigour, establishment techniques must be correct. We recommend the following:

1. Remove competition by cultivation or herbicide application.

2. In cultivated paddocks ensure a tine, well compacted tihh. 
3. Apply lime on acid soils ( $\mathrm{pH}$ less than 5.2).

4 . Inoculate the seed at 5 times the manufacturer's stipulated rate with the incorporation of $10 \%$ gum arabic and sow within one day. On acid soils (around pH 5.5 and lower) pellet seed with lime and sow within one day.

5 Broadcast seed or drill at not more than $12 \mathrm{~mm}$ deep.

6. Sow as pure sward or with a compatible companion species.

7. Use stock grazing to control light competition during seedling establishment.

8. Manage the established pasture under a rotational grazing regime.

\section{REFERENCES}

Brash. D.W. 1983. Dryland lucerne establishment by overdrilling in Central Otago. Proceedings of the NZ Grassland Association 44: 164-169.

Cullen, N.A. 1971. Establishment of pasture on yellowbrown loams near Te Anau IX. The effect of nitrogenous fertilisers on establishment of new pasture. NZ journal of agricultural research 14: 40-46.

Farrell, J.A.K.; Sweney, W.J. 1974. Plant resistance to the grass grub Costelvtra zealandica (Coleootera : Scarabaeidae) III. Resistance in Lotus and Lupinus. NZ iournal of agricultural research 17: 69-72.

Greenwood, R.M.; Pankhurst, C.E. 1977. The Rhizobium component of the nitrogen-fixing symbiosis. Proceedings of rhe NZ Grassland Association 38(1): 167-174.
Hughes, J.C. 1973. High country production survey 1971-n. Tussock Grasslands and Mountain Lands Institute Review 26: 68-76.

Lowther, W.L.; Hay, R.J.M.; Ryan, D.L. 1987. Effect of strain of rhizobia. lime. and phosphorus on dry matter vield of three lotus species in differing environments in Otago and Southland. $N Z_{\mathrm{u}}$ iournal of experimental agriculture 15: 135-142.

Lowther, W.L.; Hoglund, J.H. ; Macfarlane, M.J. 1989. Aspects that limit the survival of legume seedlings. pp 265-275. In Marten et al. (Eds). Persistence of forage legumes. ASA. CSSA. SSSA. Madison, USA.

Lowther," W. L. ; Trains., K.D. 1988. Legumes. Seed inoculation and coating. Tussock grasslands procedure. AgLink FPP 887.

Matches, A.G. 1989. A survey of legume production and persistence in the United States. pp 37-44. In Marten et al. (Eds). Persistence of forage legumes. ASA, CSSA, SSSA, Madison, USA.

Pollock, K.M. 1989. Grass establishment and performance on a high country soil fertilised with nitrogen. $\boldsymbol{N Z}$ journal of agricultural research 32: 7-15.

Seaney, R.R.; Henson, P.R. 1970. Birdsfoot trefoil. Advances in agronomy 22: 119-157.

Scott, D.; Charlton, J.F.L. 1983. Birdsfoot trefoil (Lotus corniculatus) as a potential dryland herbage legume in New Zealand. Proceedings of the NZ Grassland Association 44: 98-105.

Widdup, K.H.; Keoghan, J.M.; Ryan, D.L.; Chapman, H.M. 1987. Breeding $\boldsymbol{L}$. corniculatus for South Island tussock country. Proceedings of the NZ Grassland Association 48: $\quad 119-124$. 